\title{
Conceptual Framework for Shari'ah Corporate Governance with Special Focus on Islamic Capital Market in Malaysia
}

\author{
Nawal Kasim, Sheila Nu Nu Htay, and Syed Ahmed Salman
}

\begin{abstract}
Corporate governance issue emerged with the birth of the corporations. Similarly, the need for Shari'ah corporate governance is given attention by the regulators, industrial players, Shari'ah advisors and researchers with the bloom of Islamic finance. There are limited literature and Shari'ah governance guidelines available for Islamic financial institutions. The existing guidelines are general and they not as specific as conventional guidelines. In addition, there is no Shari'ah governance guideline for Islamic capital market in Malaysia. Therefore, this paper aims to propose conceptual framework for Shari'ah corporate governance with special focus on Islamic capital market by integrating the conventional concepts of governance. We believe that the concept of Islamic accountability, independency, competency and transparency should be the basic foundation in developing the conceptual framework for Shari'ah corporate governance.
\end{abstract}

Index Terms-Conceptual framework, Islamic capital market, Malaysia, Shari'ah governance.

\section{INTRODUCTION}

Financial institutions such as banks and insurance and financial market, i.e. capital market, are the backbone for the development of the country economy. They are the main mechanisms to mobilize the flow of funds. Conventional finance is functioning based on the concept of lending and borrowing, consequently it involves the interest, uncertainty and gambling. From the Islamic perspective, these elements are prohibited. This attracts the attention of Muslim scholars to come out with Islamic financial institutions and markets which operate within the boundary of Shari'ah while providing the services similar to the conventional counterpart. Thus, the main difference between conventional and Islamic finance is that Islamic financial institutions and market needs to operate based on the concept and principles of Shari'ah.

Islamic finance industry (IFI) has grown very fast within a short period and the regulators and international organizations have laid down the required rules and regulations for the IFI in order to ensure that the objective, i.e. Maqasid Shari'ah, is achieved. Since this industry is offering the products which are comparable with conventional while observing the Shari'ah, the industrial players and Shari'ah scholars are cracking their heads to come out with the products which are both Shari'ah compliant and compatible with the conventional products. Thus, this industry is full of many complex and sophisticated

Manuscript received June 20, 2013; revised August 21, 2013.

Nawal Kasim is with Accounting Research Institute, Universiti Teknologi Mara (e-mail: nawal120@salam.uitm.edu.my). products. Subsequently, keeping track of these transactions has become challenging to all involved parties such as bankers, accountants, auditors, policy makers, marketing officers and Shari'ah advisors. Furthermore, the fast growing market needs to be reviewed and revised frequently to meet the needs of the market while ensure Shari'ah compliance.

The concerns for Shari'ah compliance have brought a new dimension of governance which falls under the corporate governance framework. This is somewhat unique to the Islamic system of financial management [1]. The fundamental role of Shari'ah governance is to ensure that the operations of the Islamic finance activities comply with the Shari'ah and the rights of the involved parties are not violated. As far as the literature on Shari'ah governance is concerned, it remains limited since the subject is relatively new [2]-[4]. As far as the Shari'ah governance guidelines are concerned, Bank Negara Malaysia BNM) has issued it. The leading international organizations in Islamic finance such as Islamic Financial Service Board (IFSB) and Accounting and Auditing Organization for Islamic Financial Institutions (AAOIFI) have provided the guidelines on Shari'ah governance. However, to the extent of our knowledge, all the existing Shari'ah governance guidelines are still focusing on the Islamic financial institutions such as Islamic banks and Takaful operators and there is no specific Shari'ah governance framework for Islamic capital market (ICM). Therefore, the objective of this paper is to propose the conceptual framework for Shari'ah corporate governance specific for ICM in Malaysia.

This paper is organized in six sections. Section Two highlights the need for Shari'ah corporate governance of ICM. Section Three discusses the prevailing Shari'ah governance guidelines. Section Four explains some of the recommendations of conventional corporate governance that should be applied Shari'ah corporate governance for ICM. Section Five proposes the conceptual framework of Shari'ah corporate governance for ICM and the last section concludes.

\section{NEED FOR CONCEPTUAL FRAMEWORK FOR SHARI'AH CORPORATE GOVERNANCE: FOCUS ON ISLAMIC CAPITAL MARKET IN MALAYSIA REVIEW STAGE}

The concept and foundation of Islamic finance is based is the Shari'ah and it is mandatory for the Islamic financing activities to comply with it [3]. Grais and Pellegrini [5] state that from the Islamic perspective, the interests of all the stakeholders should be considered and they should be treated fairly. The Shari'ah Governance Framework issued by BNM states that:

"Shari'ah principles are the foundation for the practice of 
Islamic finance through the observance of the tenets, conditions and principles espoused by Shari'ah. Comprehensive compliance with Shari'ah would bring confidence to the general public and the financial markets on the credibility of the Islamic finance operations".

In our opinion, Shari'ah compliance of ICM is on the shoulders of Shari'ah board members. [6] and [1] state that the Shari'ah board is a crucial committee in ensuring all the transactions and operations are in line with Shari'ah. Furthermore, the top management and the conventional board of directors should fully support the dictates of the Shari'ah board so that they can be implemented successfully. [5] and [1] empathize on the credibility of the Shari'ah board while ensuring the legitimacy of the products. They have raised four main issues related to Shari'ah board members. First, the issue is related to the independence of the Shari'ah board in executing its duties. They suggest that there should be a framework which provides the criteria to identify whether Shari'ah board members are independent. Secondly, regarding the competency of Shari'ah board, there should be a guideline which mentions the minimum required qualification and expertise to be the Shari'ah board members. In addition, the relevant training should be given so that the Shari'ah board members are well-versed in operating activities of the Islamic financing activities. Thirdly, in the case of conflict of interest and confidentiality, there should be restriction on the number of directorship held by each Shari'ah board members. Another possible cause of conflict of interest is due to the remuneration. In Malaysia, the remuneration of the Shari'ah board members is decided by the management and in our opinion, to certain extent, it might impair their objectivity in providing the advisory service. Finally, the issue is related to weakness in disclosure and less transparency. According to [1] transparency can gain the confidence of the public. His findings illustrate the low level of disclosure on Shari'ah pronouncement and contents of Shari'ah rulings. Moreover, the Shari'ah audit and review are not disclosed by the majority of the Islamic financial institutions. This shows that the majority of investors and depositors are not sure of the Shari'ah review process executed by the Islamic financial institutions. His study shows that in Malaysia, GCC countries and the UK, there is a common neglect for disclosure and transparency aspects of Shari'ah pronouncements. Thus, there is a need for the conceptual framework for Shari'ah corporate governance with special focus to ICM in Malaysia. Subsequently, good Shari'ah governance would guarantee an organized review process which would ultimately fulfill its objective of complying with the Shari'ah.

\section{Conceptual ReVIEW ON THE PREVAILING Shari'AH GOVERNANCE GUIDELINES}

The objective of this research is to propose the conceptual framework for Shari'ah corporate governance with special focus on ICM in Malaysia; we discuss the existing Shari'ah governance guidelines for Islamic financial institutions. IFSB [7] also emphasizes on the four main functions of Shari'ah board members. The first function is the issuance of Shari'ah pronouncement which has to be carried out through appropriate due processes by having a rigorous deliberation among the Shari'ah board members and after scrutinizing the legal contract and other documentation relevant to the transaction. Second is the dissemination of information on Shari'ah pronouncements to the operative personnel. Third is the recommendation for an internal Shari'ah compliance review or audit in order to confirm the operations are in line with the Shari'ah. Any non-compliance should be recorded and reported. Moreover, this non-compliance should be rectified without any delay. Lastly, it suggests carrying out an annual Shari'ah compliance review or audit to ensure that the internal Shari'ah review has been appropriately conducted and the Shari'ah board has been duly informed. Moreover, it also provides the guidelines on competence, independence, confidentiality and consistency of Shari'ah board members.

As far as AAOIFI is concerned, it has seven standards for Shari'ah governance [8]. Standard No.1 provides the guidelines for the appointment and composition of Shari'ah board members. Standard No.2 discusses Shari'ah review and Standard No.3 elaborates on the internal Shari' ah review. Standard No.4 elaborates on the audit and governance committee and Standard No.5 presents the important role of the independence of the Shari'ah supervisory board. Standard No.6 states the statement on governance principles and Standard No.7 on corporate social responsibility conducts and disclosure for Islamic financial institutions.

The common ground held by these different bodies is that it provides standards that evaluates on the basis of competence, independence, confidentiality and consistency. According to [9] there are four pillars of Shari'ah governance and they are management and supervision, Shari'ah advisory, Shari'ah compliance and review, and transparency and disclosure. Regarding management and supervision, AAOIFI, IFSB and BNM recommend that management should take responsibility with the advice of Shari'ah board members to ensure the operations are compliant with Shari'ah. In the case of advisory and supervisory role, AAOIFI states that the board members should be independent and specialized jurists in Fiqh al Muamalat (Islamic commercial jurisprudence) and they are entrusted with the duty of directing, reviewing and supervising. The activities of Shari'ah board should thus be regulated. Furthermore, all the prevailing standards issued by AAOIFI, $\mathrm{BNM}$ and IFSB have provided the guidelines with regards to their competence, independence, confidentiality and consistency.

AAOIFI defines Shari' ah review as "an examination of the extent of an Islamic financial institution's compliance in all its activities with the Shari'ah. This examination includes contracts, agreements, policies, products, transaction, memorandum and articles of association, financial statements, reports and circulars". Both AAOFI and IFSB standards provide guidelines on Shari'ah review procedures and internal Shari'ah review. These guidelines point out how the internal and external Shari'ah review should take place. Moreover, the guidelines indicate the elements that should be investigated such as the agreements and financial reports. Furthermore, examination of the operation of an IFI both ex-ante and ex-post is asserted. BNM Shari'ah governance 
has stated only the need for Shari'ah review.

Transparency and disclosure play a major role in providing information of the operations. It is the right of the parties involved to know the activities carried out to build the trust and to clear any ambiguity. AAOIFI and IFSB state that there should be a high standard of reporting that provides adequate information to the shareholders and regulators. Moreover, there should be a high level of transparency and market discipline to build the trust of the shareholders and investors.

It can be summed that the ultimate objective to achieve Shari'ah compliance can only be achieved by the collective supports from all involved parties. Shari'ah board members play a crucial role to guide the management and subsequently the management should be responsible to implement it in all aspects of the operating activities. All the standards collectively emphasize on the competence, independence of Shari'ah board members and their roles in Shari'ah management and supervision, Shari'ah advisory, Shari'ah compliance and review and transparency and disclosure of the information."

\section{INTEGRATING THE CONCEPT OF CONVENTIONAL CORPORATE GOVERNANCE}

Shari'ah governance guidelines issued by AAOIFI, IFSB and BNM have suggested the Shari'ah board members to have the qualitative characteristics such as competency, independency, confidentiality and consistency. In addition, they further demand the Shari'ah board members to provide effective services such as management and supervision, Shari'ah advisory, Shari'ah compliance and review, and transparency and disclosure of the information. However, in our opinion, these standards are too general to follow. Thus, we believe that the concept of conventional corporate governance should be integrated in order to ensure that Shari'ah board members can mold the ICM operating activities. It has been supported by [10] who states that it will be practical and effective if the Shari'ah board is placed under the European Corporate Governance.

According to [11] and other several corporate governance guidelines suggest:

1) To achieve independence of the board, CEO and Chairman should not be the same person. In terms of board composition, majority should be independent and at least one third should be independent. Definition of independence may vary from one country to another, for instance, independence means free from the ownership of substantial number of shares, not being the main suppliers and the owner should not be the spouse. In addition, it is compulsory to disclose the directors' remuneration and their share interest in the company.

2) In terms of competency, all the annuals reports from the public listed companies are required to disclose clearly the profile of board of directors and it is indirectly forcing the companies to recruit the competent and experienced directors.

3) In terms of confidentiality and consistency in providing the service from the directors, it is not much encouraged a director to hold many directorships.

\section{PROPOSEd CONCEPTUAL FRAMEWORK FOR SHARI'AH CORPORATE GOVERNANCE: ISLAMIC CAPITAL MARKET IN MALAYSIA}

We propose that the conceptual framework for Shari'ah corporate governance should be based on the concepts of Islamic accountability, independency, competency and transparency. The Chairperson of Shari'ah board should not be the same person with the head of the internal Shari'ah committee. Regarding with Shari'ah board composition, all of them should be independent by meeting the criteria of independence discussed in section 4.0. In addition, their remuneration and their share interest should be disclosed in detail. Regarding competency, the board members should have qualification in Shari'ah as well as operational aspect of the ICM. To keep the information confidential and to avoid the conflict of interest, they should not hold more than one board seat. In terms of information disclosure on Shari'ah compliance of ICM, the whole process including how to prepare, review and audit to ensure compliance with Shari'ah should be disclosed. Their corporate profiles, their attendance of the meetings and etc. should be disclosed as comprehensive as the disclosure about the conventional board of directors. Finally, Shari'ah compliant report should be in-cooperated in the annual reports. This report should be comprehensive enough for the users to know how the ICM players are complying with the Shari'ah.

\section{CONCLusion}

This paper aims to explore the conceptual idea to provide the foundation for ICM players to come out with Shari'ah Corporate Governance for Islamic Capital Market in Malaysia. It is believed that the awareness of Islamic accountability should be in the hearts of Shari'ah board members and their independency will lead to the hundred percent Shari'ah compliant ICM. Since this paper is a conceptual paper, no empirical study has been conducted. Thus, future research should focus on it. We believe that this paper will be the interest of the regulators and the industrial players for developing Shari'ah Corporate Governance for Islamic Capital Market in the future.

\section{REFERENCES}

[1] Z. Hasan, Shari'ah Governance in Islamic Banks, Edinburgh: Edinburgh University Press Ltd, 2012.

[2] A. Rahman, "Shar'ah audit for islamic financial services: the need and challenges," ISRA Islamic Finance Seminar, Kuala Lumpur, pp. 1-13, 2008.

[3] M. A. Laldin, "The role of Shari'ah advisors in the development of Islamic securities, in fundamentals and practices in Islamic finance," ISRA Series in Contemporary Islamic Finance, Kuala Lumpur, 2008.

[4] S. Akhtar, "Shariah compliant corporate governance," presented at Annual Corporate Governance Conference, Dubai, 2006.

[5] W. Grais and M. Pellegrini, "Corporate governance in Islamic offering Islamic financial services," World Bank Policy Research Working Paper, November 2006.

[6] S. Alnasser and J. Muhammed, "Introduction to corporate governance from Islamic perspective," Humanomics, pp. 220-231, 2012.

[7] Guiding Principles on Shari'ah Governance System for Institutions offering Islamic Financial Services, Islamic Financial Services Board, December 2009.

[8] Accounting, Auditing and Governance Standards for Islamic Financial Institutions, Bahrain: Accounting and Auditing Organization for Islamic Financial Institutions, 2010. 
[9] I. H. Minhas, "Shari'ah Governance Model (SGM) and its four basic pillars," Islamic Finance News Malaysia, April 18, 2012.

[10] M. Casper, "Shari'ah boards and Shari'ah compliance in the context of european corporate governance," Social Science Research Network, 2012.

[11] Malaysian Code on Corporate governance, 2012.

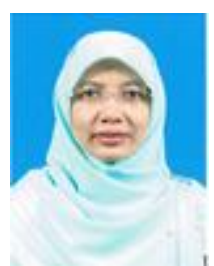

Nawal Kasim was born in Malaysia on June 14, 1961. She obtained her Ph.D. in Accounting from the International Islamic University Malaysia (IIUM), Kuala Lumpur, Malaysia in 2009, specializing in auditing from the Islamic perspective. She is an associate professor at the Faculty of Accountancy, University Teknologi MARA, Shah Alam, Malaysia. For the past three years, she has been attached as a research fellow to the Accounting Research Institute of Higher Ministry of Education (ARI HICoE), heading the institute's Islamic Accounting \& Mu'amalat Research Centre (IAMRC). She has written articles such as "Shariah auditing in Islamic Financial Institutions: Exploring the gap between the 'Desired' and the "Actual'" in the Global Economy \& Finance Journal, Vol 2, No. 2, pp 127-137 (2009), "Crime Prevention in Islamic Institutions: Practices in Brunei Darussalam" in the Malaysian Accounting Review, Vol. 9, No. 2, pp 1-9 (2009) and "The influence of the concept of 'Taklif' to accountants in preventing fraudulent financial reporting and auditing" in the Malaysian Accounting Review, Vol. 9, No.2, pp 71-83 (2010). Her research interest is in the areas of financial reporting, corporate governance and auditing. Dr Kasim was involved as a working group member for International Shariah Research Academy (ISRA), a research wing of the Central Bank of Malaysia and panel specialist (in the area of Islamic Accounting) for the Ministry of Higher Education to come up with a Standard Program for Islamic Finance \& Mu'amalat for Public/Private Universities. She was appointed as journal reviewers for Malaysian Accounting Review, Journal of Financial Reporting and Asian Academy of Management Journal of Accounting \& Finance. Currently she has been appointed as panel specialist for Master of Muamalat and Shariah Audit syllabus review for Universiti Sains Islam Malaysia. She is also a member of the Malaysian Institute of Accountants.

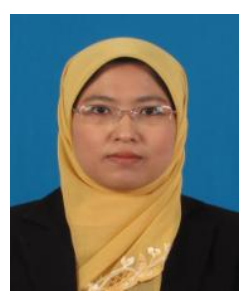

Sheila Nu Nu Htay was born in January 14, 1974 in Mandalay, Myanmar. She has completed her bachelor, master and Ph.D. in accounting from International Islamic University Malaysia in 2009. She is an assistant professor and Ph.D. programme coordinator at Institute of Islamic Banking and Finance, International Islamic University Malaysia (IIUM). Her area of expertise covers accounting for Islamic banks, Takaful and Re-takaful Companies and Islamic capital markets. She has written several books. Among them, "Accounting, Auditing and Governance for Takaful Operators" is published by John Wiley and Sons pte. Ltd. in 2012 and "Financial Accounting and Reporting for Islamic banks" will be published by IBFIM in September, 2013. Moreover, she has published a number of articles. Some of them are "Shariah Scholars' View Point on the Practice of Underwriting and Risk Rating for Family Takaful Model" and Critical Analysis on the Choice of Takaful (Islamic Insurance) Operating Models in Malaysia.

Dr. Sheila is a financial and Shari'ah compliance advisor for Myint Myat Phu Zin Clinic (waqf, zakat and charity based clinic) in Myanmar, committee Member for Islamic Finance Education Cluster (EPP7), reviewer and member of editorial board (The Journal of Islamic Finance) and reviewer for conference papers and articles by World Business Institute Pty Ltd. Australia. She has received a couple of awards such as best paper award, best lecturer award and best manager award and many more.

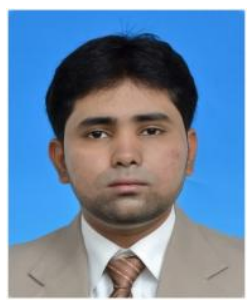

Syed Ahmed Salman was born on September 14, 1984 in Hyderabad, India. He has completed his bachelor degree in Shariah and jurisprudence from Darul-uloom Nadwatul Ulama Lucknow, India in 2008 and master of science in Islamic Banking and Finance from IIUM Institute of Islamic Banking and Finance, International Islamic University Malaysia in 2012. Currently he is a Ph.D. candidate at IIUM Institute of Islamic Banking and Finance. He is a vice president of Madarse Ashfaq- ul-uloom in Hyderbabd, India and assistant editor of monthly magazine "Al Alai" in Hyderbad, India. He has presented several research papers at national and international conferences and had a number of articles published in peer-reviewed academic journals. His areas of expertise include Shari'ah Law, Islamic banking, corporate governance and Takaful. He has published a number of articles among them "Shariah Scholars' View Point on the Practice of Underwriting and Risk Rating for Family Takaful Model", Prospects of Islamic Insurance in India, Future of Islamic Insurance (Takaful) in India and Nomination and Hibah issues in Malaysian Takaful industry. 